\title{
The Decline of Vitality Caused by Increasing Drought in a Beech Provenance Trial Predicted by Juvenile Growth
}

\author{
Anikó Horváth ${ }^{1 *}$, Csaba Mátyás ${ }^{1}$ \\ (1) University of West Hungary, Faculty of Forestry, Institute of Environmental and Earth \\ Sciences, Cházár András square 1, H-9400 Sopron, Hungary \\ * Correspondence: e-mail: hani@emk.nyme.hu
}

\begin{abstract}
Citation: HORVÁTH A, MÁTYÁS CS 2016 The Decline of Vitality Caused by Increasing Drought in a Beech Provenance Trial Predicted by Juvenile Growth. South-east Eur for 7 (1): 21-28. DOI: http://dx.doi. org/10.15177/seefor.16-06
\end{abstract}

Received: 27 Jan 2016; Revised: 10 Mar 2016; Accepted: 11 Mar 2016; Published online: 25 Mar 2016

\begin{abstract}
Background and Purpose: Due to rapidly changing environmental conditions, locally adapted tree populations are likely to experience climate conditions to which they are not well adapted. Common garden experiments provide a powerful tool for studying adaptive responses in changing climates. Out of the 1998 series of international beech provenance trials, one experiment was established in Bucsuta, SW Hungary. Because of its peripheral location, this is probably the most apposite site in the experimental series to study and predict responses of populations to sudden climatic changes, simulated by transfer.

Material and Methods: 15-year diameter data of 28 beech populations from different regions of Europe were used to mimic responses to climate change by transplantation to the test site. The effect of 17 climate variables and five derived climate indices on growth have been compared, while Ellenberg drought index (EQ) was selected for calculating a linear regression (transfer function) to project a growth trend for future climate change.

Results: Out of the bioclimatic variables, Ellenberg drought index at the location of the origin of provenances has shown the best correlation with 15-year diameter. The regression of growth vs. the ecodistance of transfer (difference between data of the trial site and of the site of origin), expressed in EQ, explained $25 \%$ of the total variation between provenances and indicated a clear trend of declining performance with the increasing change of climate the populations were adapted to. Conclusion: Negative effect of rapid climate change on beech populations cannot be denied, and the results draw attention to the importance of using appropriate planting stock matching with future climate conditions at the planting site.
\end{abstract}

Keywords: common garden, xeric limit, increment loss, Ellenberg drought index, adaptation

\section{INTRODUCTION}

Tree species are threatened by projected increasing temperatures and an increased frequency of extreme events [1]. In Central-Southeast Europe, the increasing magnitude and frequency of summer droughts is a particular threat [2]. While climatic warming in the northern part of the range may lead, with sufficient precipitation, to production increase, under the stressful and uncertain conditions at the receding, xeric limit growth depression and vitality loss are expected $[3,4]$. It is assumed that many tree species will be unable to adapt to rapid climate change due to their low migration rate $[5,6]$ and to highly fragmented landscapes [7].
In Southeast and South Europe, the most important factor limiting the occurrence of European beech (Fagus sylvatica L.) is precipitation, and therefore peripheral or marginal populations at the low-elevation (xeric) limit require special attention [8]. In some studies growth decline caused by the worsening of climate conditions has been demonstrated already at the xeric limit $[4,9,10]$.

It has been demonstrated that different genetic architecture of beech populations exist. However, there is no complete agreement on reasons for the transeuropean variation pattern, which depends on how much weight is given to the effect of postglacial migration [11, 12]. In this paper we trace possible effects of adaptation to local 
climatic conditions on the tolerance of populations to rapid climate change, not excluding the possibility of other effects shaping the within-species genetic variation pattern of beech. In common garden experiments important adaptive traits such as frost and drought resistance or growth characteristics of populations may be compared, and therefore these tests provide a valuable basis for recommendations for the use and transfer of forest reproductive material in the face of climate change [13, 14].

\section{MATERIALS AND METHODS}

\section{Concept of the Analysis}

Differential climate selection pressure as the main reason for genetic variation in beech between provenances has been taken as basic the hypothesis to be proven in this study. For studying climatic adaptation and populationspecific response of trees, common garden (provenance) experiments provide a powerful tool. The importance of these experiments lies also in their potential to mimic projected climate change effects [15-18]. According to this interpretation populations are adapted to certain ecological (climatic) conditions and if they are transferred to a new environment, their phenotypic response to climate depends not only on the climatic conditions where the population is tested, but also on the magnitude and direction of environmental change experienced due to the transplanting, which is related to the macroclimate they had been adapted to originally. The ecological difference between the two climates was termed "ecodistance" which expresses the environmental (climatic) effect of transfer [19]. For instance, in case of temperature, positive ecodistance values mean that provenances are subjected to warmer conditions at the test site than at the original site.

Consequently, common garden tests may yield estimates for the effects of climatic changes and it is therefore advisable to reanalyze and utilize all available information and data not evaluated before, even in tests which do not meet rigorous statistic requirements. In what follows 15-year data of a test of particular interest in Hungary have been assessed, applying the ecodistance concept.

\section{The International Beech Provenance Trials of IUFRO}

In 1995 and 1998 international beech provenance trials were established across Europe, organized by the Institute for Forest Genetics, Grosshansdorf, Germany, initiated by H.J. Muhs and G. von Wühlisch [20]. Seeds were collected from the whole distribution area and raised in Hamburg in the nursery until age two. With support of a large number of participants, 42 tests were successively planted across Europe. The layout of the planting was uniform at each site. Provenances were planted in randomized plots of $10 \times 10 \mathrm{~m}$ size, 50 plants per plot (5 rows each with 10 plants, in $2 \times 1 \mathrm{~m}$ spacing) and replicated in three blocks. The provenances represented in the parallel trials were not always the same and the dates of measurements were also different.

\section{The Hungarian Provenance Trial in Bucsuta}

Out of the 1998 series of the international beech provenance trials, one experiment was established in Bucsuta, SW Hungary. The experiment was initiated by Cs. Mátyás. The trial is located in the Forest District of Bánokszentgyörgy (SW Hungary), subcompartment Bucsuta $10 \mathrm{~B}\left(46^{\circ} 35^{\prime} \mathrm{N}, 16^{\circ} 51^{\prime} \mathrm{E}\right)$ managed by the Zalaerdő State Forest Company. It is situated at the altitude of approx. $220 \mathrm{~m}$ above sea level on a southeast-facing slope with an inclination of about $5-10^{\circ}$. The site belongs to the hilly forest region of Göcsej with temperate-continental climate with some Alpine/sub-Mediterranean influence. The soils are deep, lessivé brown forest soils on loess bedrock, with favorable water holding capacity. The dominant tree species in the region is beech, frequently associated with sessile oak (Quercus petraea (Matt.) Liebl.), non-autochthonous Scots pine (Pinus sylvestris L.) and hornbeam (Carpinus betulus L.). On the selected site a 31-year-old Norway spruce forest stand was originally growing, heavily damaged by spruce bark beetles (Ips typographus) It was clear-cut the previous winter, tree stumps were removed and the trial area was fenced.

In the Hungarian trial four provenances out of the 36 are Hungarian (Table 1). The provenance Magyaregregy belongs to the international set, i.e. it is represented in some other trials, while the three others were added to complete the trial set to 36. One of these, Bánokszentgyörgy, originates from the nearby forests and may be considered local. The outplanting of the 36 provenances in 3 replications followed the original plans.

Bucsuta is a particularly interesting location for studying adaptive responses. Because it is situated at the edge of the distribution area (at the xeric limit), most provenances here experience warmer and drier climate than at their site of origin. Figure 1 shows climate location of Bucsuta and of all provenances which are represented at the site. In Bucsuta, mean average rainfall was $707 \mathrm{~mm}$ per year and the mean temperature in July was $21^{\circ} \mathrm{C}$ for the analysis period. There is only one provenance (Pyrenées, FR) which had a higher July mean temperature than Bucsuta. The majority of sources were adapted to higher rainfall at their places of origin (Figure 1).

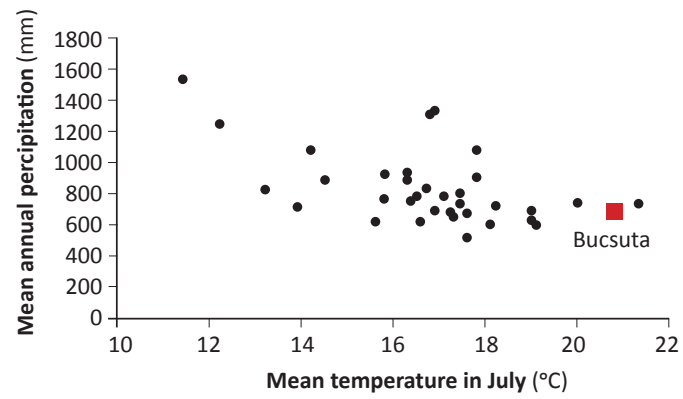

FIGURE 1. The location of Bucsuta and of the analysed provenances in the climatic space of annual precipitation and July mean temperature [20] 
TABLE 1. Geographic data, the annual sum of precipitation and July mean temperature (for the period 1950-2000) of provenances, as well as their ecodistance, expressed in Ellenberg drought index ( $\triangle \mathrm{EQ})$, ranked by 15-year diameter data in Bucsuta (in \% of the "theoretical local" performance*; see explanation in the text).

\begin{tabular}{|c|c|c|c|c|c|c|c|c|}
\hline Name of provenance & Country & Latitude & Longitude & $\begin{array}{l}\text { Altitude } \\
(\mathrm{m})\end{array}$ & $\begin{array}{c}\text { Annual sum of } \\
\text { precipitation }(\mathrm{mm})\end{array}$ & $\begin{array}{c}\text { Mean temperature } \\
\text { in July }\left({ }^{\circ} \mathrm{C}\right)\end{array}$ & $\Delta \mathrm{EQ}$ & $\begin{array}{c}\text { Mean } \\
\text { Diameter (\%) }\end{array}$ \\
\hline Magyaregregy & $\mathrm{HU}$ & 46.22 & 18.35 & 400 & 707 & 19 & 2.57 & 122.09 \\
\hline Farkasgyepü & $\mathrm{HU}$ & 47.2 & 17.65 & na & 625 & 19.1 & -1.11 & 108.41 \\
\hline Soignes & $\mathrm{BE}$ & 50.83 & 4.42 & 110 & 810 & 17.4 & 7.97 & 106.64 \\
\hline Bánokszentgyörgy (local) & $\mathrm{HU}$ & 46.6 & 16.85 & 200 & 747 & 20 & 2.67 & 101.81 \\
\hline Pidkamin & UA & 49.95 & 25.38 & na & 612 & 18.1 & -0.13 & 101.25 \\
\hline Farchau & $\mathrm{DE}$ & 53.65 & 10.67 & 55 & 676 & 17.3 & 3.86 & 100.78 \\
\hline Perche & FR & 48.42 & 0.55 & 205 & 691 & 17.6 & 3.98 & 98.92 \\
\hline Tarwana & $\mathrm{PL}$ & 49.47 & 22.33 & 540 & 704 & 16.9 & 5.44 & 98.27 \\
\hline Jaworze & PL & 49.83 & 19.17 & 450 & 950 & 16.3 & 12.29 & 96.78 \\
\hline Nizbor & $\mathrm{CZ}$ & 50 & 14 & 480 & 541 & 17.6 & -3.08 & 93.62 \\
\hline Bordure Manche & FR & 49.53 & 0.77 & 80 & 689 & 17.6 & 3.9 & 91.76 \\
\hline Pyrenées & FR & 42.92 & 2.32 & 670 & 754 & 21.3 & 1.2 & 91.29 \\
\hline Graf von Westphalen & $\mathrm{DE}$ & 51.52 & 8.78 & 375 & 941 & 15.8 & 12.66 & 90.82 \\
\hline Idrija & $\mathrm{SI}$ & 46 & 13.9 & 930 & 1318 & 16.8 & 16.7 & 90.82 \\
\hline Dillenburg & $\mathrm{DE}$ & 50.7 & 8.3 & 520 & 751 & 17.4 & 6.28 & 87.85 \\
\hline Koino & PL & 49.92 & 20.42 & 400 & 729 & 18.2 & 4.48 & 86.36 \\
\hline Bilowo & $\mathrm{PL}$ & 54.33 & 18.17 & 250 & 631 & 15.6 & 4.73 & 82.82 \\
\hline Oberwil & $\mathrm{CH}$ & 47.17 & 7.45 & 570 & 923 & 17.8 & 10.16 & 82.64 \\
\hline Ebrach & $\mathrm{DE}$ & 49.85 & 10.5 & 406 & 701 & 17.2 & 4.91 & 81.70 \\
\hline Aarnink & NL & 51.93 & 6.73 & 45 & 797 & 17.1 & 7.99 & 81.61 \\
\hline Brumov-Sidonie & $\mathrm{CZ}$ & 49.05 & 18.05 & 390 & 799 & 16.5 & 8.8 & 79.75 \\
\hline Buchlovice & $\mathrm{CZ}$ & 49.15 & 17.32 & 410 & 669 & 17.3 & 3.59 & 78.45 \\
\hline Westfield & GB & 57.4 & -2.75 & 10 & 836 & 13.2 & 13.66 & 75.94 \\
\hline Jablonec & $\mathrm{CZ}$ & 50.8 & 15.23 & 760 & 731 & 13.9 & 10.43 & 71.65 \\
\hline Urach & $\mathrm{DE}$ & 48.47 & 9.45 & 760 & 894 & 16.3 & 11.22 & 69.79 \\
\hline Grasten & DK & 54.92 & 9.58 & 45 & 780 & 15.8 & 9.19 & 69.05 \\
\hline Heinerscheid & LU & 50.08 & 6.12 & 423 & 844 & 16.7 & 9.66 & 68.30 \\
\hline Domazlice-Vyhledy & $\mathrm{CZ}$ & 49.4 & 12.75 & 760 & 893 & 14.5 & 13.21 & 65.70 \\
\hline Eisenerz & AT & 47.53 & 14.85 & 1100 & 1259 & 12.2 & 19.76 & excluded \\
\hline Postojna & $\mathrm{SI}$ & 45.63 & 14.38 & 1000 & 1346 & 16.9 & 16.89 & excluded \\
\hline Hinterstoder & AT & 47.72 & 14.1 & 1250 & 1539 & 11.4 & 22.04 & excluded \\
\hline Horni Plana & $\mathrm{CZ}$ & 48.85 & 14 & 990 & 1097 & 14.2 & 16.5 & excluded \\
\hline Jawornik & PL & 49.25 & 22.82 & 900 & 764 & 16.4 & 7.98 & excluded \\
\hline Ördöglyuk & $\mathrm{HU}$ & 48.49 & 21.36 & 450 & 651 & 19 & 0.26 & excluded \\
\hline Plateaux du Jura & FR & 46.8 & 5.83 & 600 & 1097 & 17.8 & 13.22 & excluded \\
\hline Torup & SE & 55.57 & 13.2 & 40 & 634 & 16.6 & 3.27 & excluded \\
\hline $\begin{array}{l}\text { Bucsuta (mean of the } \\
\text { period } 1998-2012)^{*}\end{array}$ & & 46.57 & 16.67 & 220 & 707 & 20.8 & 0.00 & 100 \\
\hline
\end{tabular}

* Bucsuta is considered as the "theoretical local" reference; na - not available. 


\section{Screening Diameter Data}

Height measurement was not practicable for most provenances due to the strong crown closure, and therefore the diameter data were used to compare growth. The assessment was carried out in the spring of 2013, when trees were 15 years old (from outplanting) at the trial site Bucsuta. Unfortunately, due to heavy losses only a part of the trial could be evaluated. The low survival was caused either by vole damage, local site problems or tolerance limitations, i.e. by the ecological effect of transplantation. In total, eight provenances were excluded from the analysis of growth response to improve the focus of the investigation. Four provenances were excluded due to very low survival (Plateaux du Jura (FR), Torup (SE), Jawornik (PL), Ördöglyuk (HU)). The other four provenances from higher altitudes were also excluded from the analysis because of their very different behavior tested before [21]. They originated from altitudes above $1000 \mathrm{~m}$ (Hinterstoder (AT), Eisenerz (AT), Horni Plana (CZ), Postojna (SI)) and have shown mostly vigorous growth despite of their high ecodistance values, which indicates that the selected climatic variable (EQ) could not capture the climate-related adaptation properly. Therefore separate analyses are needed to interpret the response of high-elevation populations.

Finally, 28 provenances out of 36 were included in the present analysis. Many plots even from these provenances had to be also disqualified due to low survival; only data of 44 plots were utilized. As no significant repetition effect was found, the plot means were pooled without adjustment for the analysis as random entries. In every plot, the mean diameter of the 5 thickest individuals has been calculated in order to minimize bias (statistical "noise") caused by suppressed or damaged trees. This method of the reduction of input data has proven to improve significance in other experiments. It has its silvicultural relevance, i.e. it concentrates on the most competitive individuals ("future trees") in the stand.

Table 1 shows data of all provenances, as well as the ones excluded from the analysis. The diameter data are presented in percents of the "theoretical local" (see further below). The listed data are means of single plots or provenance averages where more than one plot was analysed (in the statistical analysis all plots were evaluated separately).

\section{Determination Method of Climatic Ecodistances}

Climate data for the provenance's origin were obtained from the WorldClim database (www.worldclim. org), referring to the $1950-2000$ period. This period was considered as an approximation to characterize the past climate to which the parent populations had to adapt in their lifetime - and during earlier generations. The database included interpolations of station data with a spatial resolution of about one square kilometer. Regarding the reference climate data of the trial site, the weather data of only those years to which the provenances were concretely exposed was averaged, explicitly from the date of planting to the date of measurement (e.g. 19982012). Therefore the trial site climate does not refer to the meteorological standard of 30 -year averages. This way we used two different types of weather references. For the trial site at Bucsuta, the weather data of 15 years were obtained from the nearest station (Nagykanizsa, latitude: 46.45, longitude: 16.967, elevation: $141 \mathrm{~m}$ ). Comparisons of locally measured data and station data have shown acceptable agreement (not shown).

For the analysis, 17 bioclimatic variables were considered, as well as two continentality- and three aridity indices which were derived from monthly temperature and precipitation averages (Table 2).

\section{RESULTS AND DISCUSSION}

In order to select the most significant bioclimatic factor, correlation analysis was performed between climate variables of the original locations of provenance and 15-year diameter data (Table 2). Statistical analysis was conducted using STATISTICA 12. Significant correlations were obtained for the variables EQ $(p=0.007)$, Tmax $(p=0.018)$, TQW $(p=0.018)$, DMI $(p=0.031)$. Ellenberg drought index (EQ) showed the strongest relationship; Tmax as the numerator of the index was also significant. Earlier studies have already demonstrated the importance of EQ in determining the climatic niche of beech $[8,22$; the two studies resulted in practically identical EQ values, see in latter paper].

Consequently, ecodistance was expressed by the change of the most influential climate parameter, while Ellenberg drought index $(\Delta \mathrm{EQ}$ ) was calculated to describe the effect of climatic transfer on diameter. A linear response regression of diameter growth vs. $\triangle \mathrm{EQ}$ has been calculated with plot means of the selected 28 provenances. The intercept (at $\triangle E Q=0$ ) of the function has been considered to be the performance of the "theoretical local" provenance. The trial site Bucsuta is considered to be the "theoretical local" reference (see Table 1). Subsequently diameter data were transformed into percentages of the "theoretical local", i.e. into relative diameter $\left(D^{\prime}\right)$ to better illustrate the observed change in response. Figure 2 shows the linear function of growth response which explains $25 \%$ of the total variation between provenances $\left(R^{2}=0.247, p=0.0006\right)$.

The function predicts the increment loss caused by sub-optimal adaptedness, i.e. when a population is planted in an environment to which it is not fully adapted. The function may be interpreted also as the indicator of the growth decline of native populations caused by projected rapid climate change. For example, a temperature increase by $3.5^{\circ} \mathrm{C}$ (the magnitude projected by IPCC for 2100, [23]) and unchanged precipitation brings about a climatic change of $5 \Delta \mathrm{EQ}$ units on a site with $700 \mathrm{~mm}$ annual precipitation and $20^{\circ} \mathrm{C}$ mean July temperature. The function predicts for this case $10 \%$ increment loss. (The projection is optimistic, as summer precipitation will decline too.)

The provenance with the highest relative diameter (D') was a Hungarian one, Magyaregregy (122\%), from a slightly cooler site, with the same amount of precipitation as the test site (Table 1). It indicates that if precipitation is sufficient, the warming may enhance growth even close to the xeric limit. The other Hungarian 
TABLE 2. A list of tested climatic variables and results of the correlation analysis data of original sites versus 15 -year diameter in Bucsuta (variables significant at $\mathrm{p}<0.05\left({ }^{*}\right)$ and at $\mathrm{p}<0.01\left({ }^{* *}\right)$ are marked).

\begin{tabular}{|c|c|c|c|}
\hline Climate variables & Abbreviation & $\begin{array}{l}\text { Pearson correlation } \\
\text { coefficient }\end{array}$ & Significance \\
\hline Mean annual temperature & Ta & 0.345 & 0.190 \\
\hline Mean diurnal range & Thh & 0.369 & 0.160 \\
\hline Isothermality & Izoterm & -0.110 & 0.680 \\
\hline Max temperature of the warmest month & Tmax & 0.582 & $0.018^{*}$ \\
\hline Min temperature of the coldest month & Tmin & -0.014 & 0.960 \\
\hline Temperature annual range & Tah & 0.430 & 0.096 \\
\hline Mean temperature of wettest quarter & TQH & 0.060 & 0.826 \\
\hline Mean temperature of driest quarter & TQA & 0.014 & 0.958 \\
\hline Mean temperature of warmest quarter & TQW & 0.582 & $0.018 *$ \\
\hline Mean temperature of coldest quarter & TQC & 0.059 & 0.828 \\
\hline Annual precipitation & $\mathrm{Pa}$ & -0.405 & 0.120 \\
\hline Precipitation of the wettest month & Pmax & -0.181 & 0.503 \\
\hline Precipitation of the driest month & Pmin & -0.436 & 0.092 \\
\hline Precipitation of the wettest quarter & $\mathrm{PQH}$ & -0.303 & 0.254 \\
\hline Precipitation of the driest quarter & PQA & -0.345 & 0.191 \\
\hline Precipitation of the warmest quarter & PQW & -0.298 & 0.263 \\
\hline Precipitation of the coldest quarter & $P Q C$ & -0.237 & 0.377 \\
\hline Gorczinski's continentality index [25] & $\mathrm{GCT}$ & 0.460 & 0.073 \\
\hline Continentality index & CONT & 0.399 & 0.126 \\
\hline De Martonne aridity index [26] & DMI & -0.540 & $0.031 *$ \\
\hline Ellenberg index [27] & EQ & 0.642 & $0.007 * *$ \\
\hline Forest aridity index [28] & FAI & 0.415 & 0.110 \\
\hline
\end{tabular}

provenance, Farkasgyepú, also performed well (108\%). This provenance also experienced warmer climate at Bucsuta with more precipitation. The ecodistance of the "truly" local provenance (Bánokszentgyörgy) is not 0 but has a positive value $(\triangle \mathrm{EQ}=2.67)$, which shows the magnitude of local climate warming, comparing the mean of the past 50 years with the current data. For the period 1998-2012 precipitation has decreased by $40 \mathrm{~mm}$ and July temperature has increased by nearly $1^{\circ} \mathrm{C}$ compared to the climate period of 1950-2000. The climate data of the "theoretical local" reference population are identical with the current means of Bucsuta, whose relative diameter is 100\% (Table 1).

Both Atlantic and continental provenances from lower elevations had on average similar mean annual precipitation, but usually much lower mean July temperature than the current conditions in Bucsuta.
Provenances Jaworze and Tarwana (PL), as well as Perche (FR) were growing equally or insignificantly worse than the "local" reference provenance, originating from much cooler climates ( $\triangle \mathrm{EQ}$ : +3.98 to +12.29 ). Apparently, the transfer to the warmer site with sufficient precipitation caused no significant decline. Some provenances, such as Pidkamin (UA) and Nizbor (CZ) performed also relatively well. They had negative $\triangle \mathrm{EQ}$ values, not because of higher July temperatures, but due to significantly lower precipitation than Bucsuta. Domazlice-Vyhledy (CZ), Heinerscheid (LU), Grasten (DK), Urach (DE), Westfield (GB) and Jablonec (CZ) were among the weak performers; all of them had high or very high positive ecodistance values above $9 \Delta \mathrm{EQ}$, indicating a serious decline of vitality due to a strong warming effect following the transfer. There were also a few "correlation breakers": Soignes (BE) and Farchau (DE) displayed a surprising growth in spite of a 


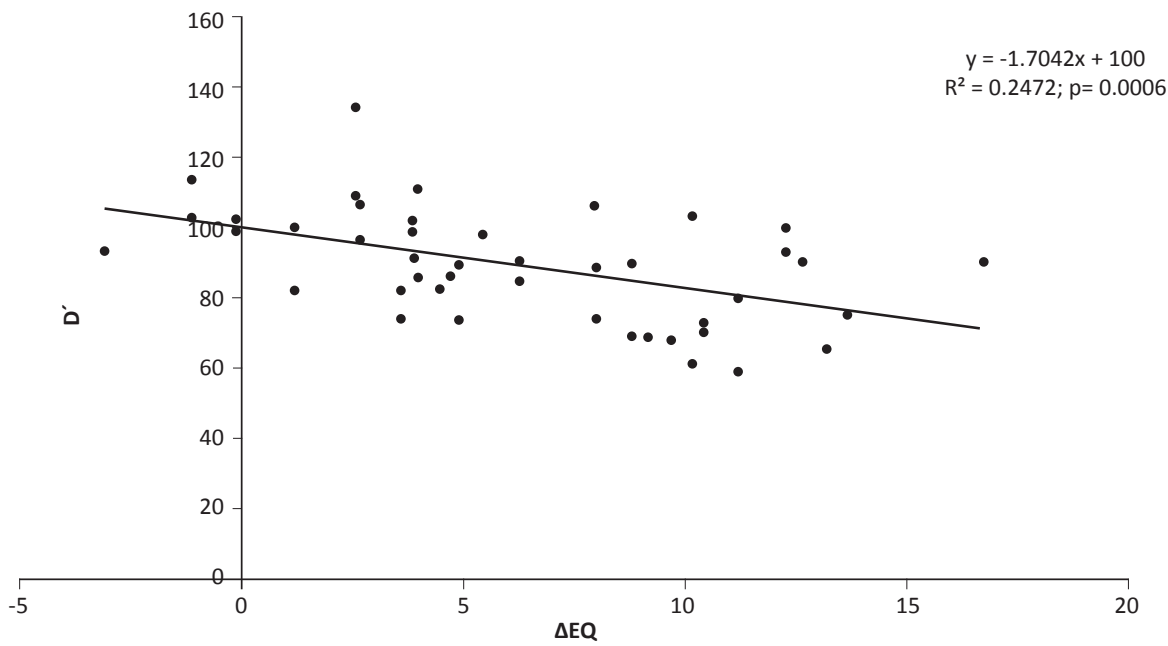

FIGURE 2. Increment decline caused by sub-optimal adaptedness. The "transfer function" defines the decline in percents of the mean diameter $\left(D^{\prime}\right)$ of the "theoretically local" provenance, in function of the change of the Ellenberg's drought index $(\Delta \mathrm{EQ})$. Data points are plot averages [13].

considerable warming effect. The latter also shows excellent stem form (Figure 3). Graf von Westphalen (DE) and Jaworze $(\mathrm{PL})$ had still shown a good diameter growth in spite of very high ecodistance of above $12 \Delta \mathrm{EQ}$. Some of the unexplained error variance and "correlation breaking" might be explained by incapability of the drought index to correctly characterize climate conditions, particularly the effect of moisture content in coastal zones, e.g. in case of Torup (see below), and in general by the uncertainties in interpolated precipitation data.

The breakdown of populations (mortality, low survival) reaching the limit of their inherited tolerance could not be modeled by growth data because of few surviving individuals. Out of the provenances excluded from the analysis due to high losses, one provenance seems to indicate this limit of tolerance under Bucsuta's climate:
Torup from Sweden. However, the ecodistance expressed in $\triangle \mathrm{EQ}$ is relatively small, only 3.27 . It may be argued that the ecodistance is not well captured with $\triangle E Q$; the population close to the northern (thermic) limit of the species is most probably adapted to low water deficit. The seemingly low mean precipitation at the original location is compensated by higher air humidity in vicinity of the sea coast. In addition, the large latitudinal distance probably affects photoperiodic behavior. It has to be mentioned that in a recent study of Norway spruce it was observed that long-day provenances from Scandinavia were more sensitive to the increase of temperature than the Central European ones [24].

Another population of high mortality, Plateaux du Jura (FR), has an extreme ecodistance value of $\Delta E Q=13.22$, which offers evidence of survival difficulties in a definitely drier environment. The cases of the other two provenances,
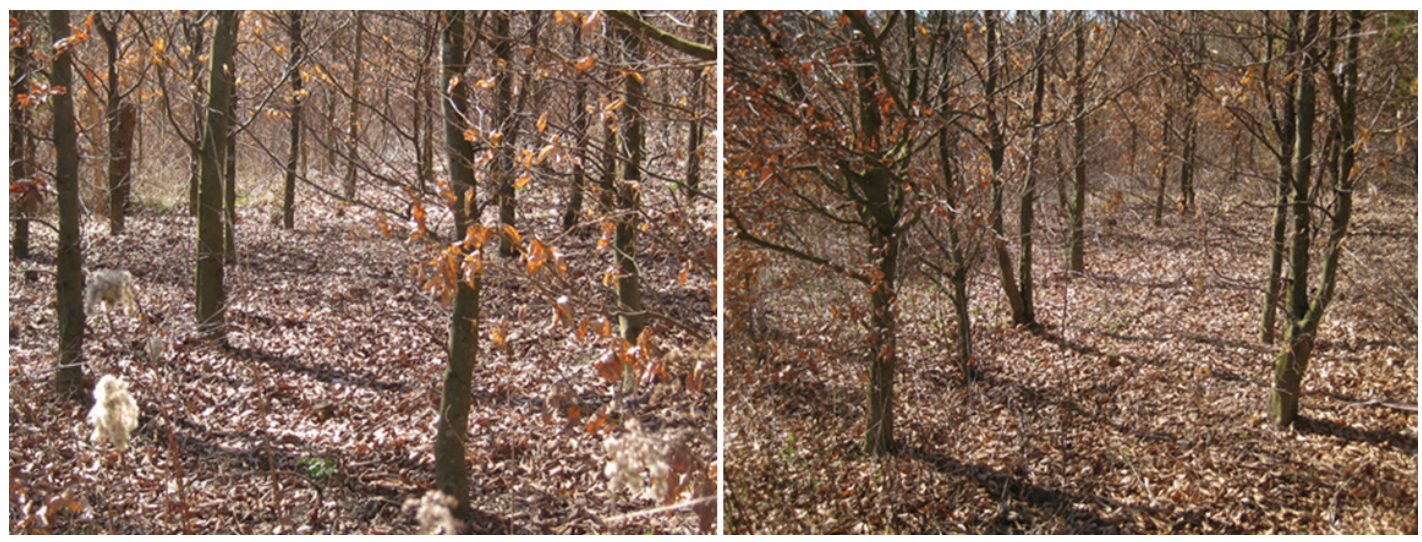

FIGURE 3. In addition to growth and survival, stem quality of provenances is an important trait. Left: Farchau (D) with an excellent stem form. Right: Farkasgyepú from Hungary presumably shows the effect of dysgenic selection in the past. 
Jawornik (PL) and Ördöglyuk (HU) cannot be explained by the available parameters. Some random effects may have caused their failure and the subsequent exclusion from the analysis.

The transfer function calculated indicates a linear decline with increasing drought index change, which is different from the theoretically expected exponential decline. The reason is the high uncertainty in the dataset which did not allow a more exact expression of the response to warming and precipitation loss. Still, due to the peripheral location of the Hungarian trial the clearly negative effect of the projected climate change may be perceived.

\section{CONCLUSION}

The test site has proven stressful to almost all tested populations. The majority of sources were adapted to higher rainfall and lower July mean temperature at their locations of origin. The effect of climatic maladaptation was tested by a specifically calculated ecodistance, expressing the change of climatic stress through transfer. Diameter data at the age of 15 indicate that in general, the warming of climate, i.e. the transfer from somewhat cooler origin, may enhance growth only if precipitation is sufficient. Populations adapted to and transferred from significantly cooler/wetter climate were under stress in Bucsuta. The obtained, linear transfer function predicts a relatively mild growth decline of juvenile populations responding to an increasing dryness. Transfers causing drastic increase of moisture stress have led to a serious loss of vitality. Strong mortality in some extreme cases offers evidence for survival difficulties when genetically set limits of tolerance are reached. There remained, however, a few "correlation breakers" the existence of which might be explained by incapability of the applied drought index to correctly characterize certain climate conditions, e.g. in high-elevation and coastal zones and by the uncertainties in interpolated precipitation data in general. In addition, the existence of other impacts on the genetic diversity such as the drift caused by postglacial migration or isolation, as well as the effects of dysgenic or positive selective pressure caused by human interference, cannot be excluded. All these uncertainties, enhanced by the survival problems at the test site, contributed to the relatively constrained adaptive response indicated by the transfer function (Figure 2). Field observations [29] support the idea that the assumed vitality decline and the appearance of large-scale mortality may be more severe than established by the discussed statistical analysis. Unquestionably, in case of predictions about the future fitness of populations on the basis of these results, it has to be remembered that these data have been obtained from juvenile trees. Further observations are indispensable to increase reliability.

In spite of the admittedly high uncertainties in the dataset, the general negative effect of rapid climate change on beech populations cannot be denied, although contradicting results also surfaced [30] which have to be carefully investigated. The results draw attention to the importance of using appropriate planting stock, matching with the future climate conditions at the planting site [13, 14].

\section{Acknowledgements}

The research was supported by FORGER FP7 joint European project and by the VKSZ_12-1-2013-0034-AGRÁRKLÍMA.2 projects.

\section{REFERENCES}

1. MÁTYÁS CS, BERKI I, GÁLOS B, CZÚCZ B, MÓRICZ N, RASZTOVITS E 2010 Future of beech in Southeast Europe from the perspective of evolutionary ecology. Acta Silvatica et Lignaria Hungarica 6: 91-110

2. BARTHOLY J, PONGRÁCZ R, HOLLÓSI B 2013 Analysis of projected drought hazards for Hungary. Advances in Geosciences 35: 61-66. DOI: http://dx.doi.org/10.5194/ adgeo-35-61-2013

3. MÁTYÁS CS, VENDRAMIN GG, FADY B 2009 Forests at the limit: evolutionary-genetic consequences of environmental changes at the receding (xeric) edge of distribution. Ann Forest Sci 66 (8): 800. DOI: http://dx.doi.org/10.1051/ forest/2009081

4. MÁTYÁS CS, BOZIC G, GÖMÖRY D, IVANKOVIC M, RASZTOVITS E 2009 Juvenile growth response of European beech (Fagus sylvatica L.) to sudden change of climatic environment in SE European trials. iForest 2: 213-220. DOI: http://dx.doi. org/10.3832/ifor0519-002

5. DAVIS ME, SHAW RG, ETTERSON JR 2005 Evolutionary responses to climate change. Ecology 86 (7): 1704-1714. DOI: http://dx.doi.org/10.1890/03-0788

6. MÁTYÁS CS 2005 Expected climate instability and its consequences for conservation of forest genetic resources. In: Geburek T, Turok J (eds) Conservation and management of forest genetic resources in Europe. Arbora Publishers, Zvolen, Slovakia, pp 465-476
7. JUMP AS, PEÑUELAS J 2005 Running to stand still: adaptation and the response of plants to rapid climate change. Ecol Lett 8 (9): 1010-1020. DOI: http://dx.doi.org/10.1111/j.14610248.2005.00796.X

8. CZÚCZ B, GÁLHIDY L, MÁTYÁS CS 2011 Present and forecasted xeric climatic limits of beech and sessile oak distribution at low altitudes in Central Europe. Ann Forest Sci 68 (1): 99-108. DOI: http://dx.doi.org/10.1007/s13595-011-0011-4

9. JEZIK M, BLAZENEC M, STRELCOVÁ K, DITMAROVÁ L 2011 The impact of the 2003-2008 weather variability on intra-annual stem diameter changes of beech trees at a submontane site in central Slovakia. Dendrochronologia 29 (4): 227-235. DOI: http://dx.doi.org/10.1016/j.dendro.2011.01.009

10. HLÁSNY T, BARCZA Z, MÁTYÁS CS, SEIDL R, KULLA L, MERGANIČOVÁ K, TROMBIK J, DOBOR L, KONÔPKA B 2014 Climate change increases the drought risk in Central European forests: What are the options for adaptation? Lesnícky Časopis - Forestry Journal 60 (1): 5-18. DOI: http:// dx.doi.org/10.2478/fori-2014-0001

11. ALÍA R, BOZIC G, GÖMÖRY D, HUBER G, RASZTOVITS E, VON WÜHLISCH G 2011 The survival and performance of beech provenances over a Europe-wide gradient of climate. In: Genetic Resources of European Beech (Fagus sylvatica L.) for Sustainable Forestry. Proceedings of the COST E52 Final Meeting. Monografías INIA, Seria Forestal 22: 115-126 
12. GÖMÖRY D, PAULE L 2010 Reticulate evolution patterns in western-Eurasian beeches. Bot Helv 120 (1): 63-74. DOI: http://dx.doi.org/10.1007/s00035-010-0068-y

13. MÁTYÁS CS 2016 Guidelines for the choice of forest reproductive material in the face of climate change. FORGER Guidelines 2016, Biodiversity International, Rome, Italy, pp 1-8

14. MÁTYÁS CS, KRAMER K 2016 Adaptive management of forests and their genetic resources in the face of climate change: Reference to the document: Climate change affects forest genetic resources: consequences for adaptive management. FORGER Policy Brief, Bioversity International, Rome, Italy, pp 1-8

15. MÁTYÁS CS 1994 Modeling climate-change effects with provenance test data. Tree Physiology 14 (7-8-9): 797-804. DOI: http://dx.doi.org/10.1093/treephys/14.7-8-9.797

16. MÁTYÁS CS 1996 Climatic adaptation of trees: Rediscovering provenance tests. Euphytica 92 (1-2): 45-54. DOI: http:// dx.doi.org/10.1007/BF00022827

17. REHFELDT GE, YING CC, SPITTLEHOUSE DL, HAMILTON DA 1999 Genetic responses to climate in Pinus contorta: niche breadth, climate change, and reforestation. Ecological Monographs 69 (3): 375-407. DOI: http://dx.doi. org/10.2307/2657162

18. REHFELDT GE, WYKOFF WR, YING CC 2001 Physiological plasticity, evolution, and impacts of a changing climate on Pinus contorta. Climatic Change 50 (3): 355-376. DOI: http:// dx.doi.org/10.1023/A:1010614216256

19. MÁTYÁS CS, YEATMAN CW 1992 Effect of geographical transfer on growth and survival of jack pine (Pinus banksiana Lamb.) populations. Silvae Genet 43 (6): 370-376

20. VON WÜHLISCH G 2007 Series of international provenance trials of European beech. In: Proceedings from the 7th International Beech Symposium IUFRO Research Group 1.10.00 "Improvement and Silviculture of Beech". Teheran, Iran, May 2004, pp 135-144
21. HORVÁTH A, MÁTYÁS CS 2014 Estimation of increment decline caused by climate change, based on data of a beech provenance trial. Erdészettudományi Közlemények 4 (2): 9199 (in Hungarian with Eglish summary)

22. FANG J, LECHOWICZ MJ 2006 Climatic limits for the present distribution of beech (Fagus L.) species in the world. J Biogeog 33 (10): 1804-1819. DOI: http://dx.doi.org/10.1111/ j.1365-2699.2006.01533.x

23. IPCC 2014 Climate Change 2014: Synthesis Report. Contribution of Working Groups I, II and III to the Fifth Assessment Report of the Intergovernmental Panel on Climate Change [Core Writing Team, Pachauri RK, Meyer LA (eds.)]. IPCC, Geneva, Switzerland, $151 \mathrm{pp}$

24. ÚJVÁRI-JÁRMAY É, NAGY L, MÁTYÁS CS 2016 The IUFRO 1964/68 Inventory Provenance Trial of Norway Spruce in Nyírjes, Hungary - results and conclusions of five decades. Acta Silvatica et Lignaria Hungarica (in press)

25. GORCZINSKI W 1920 Sur le calcul du degré de continentalisme et son application dans la climatologie. Geografiska Annaler 2: 324-331. http://dx.doi.org/10.2307/519539

26. DE MARTONNE E 1941 Nouvelle carte mondiale de l'indice d'aridité. Annales de Géographie 51: 242-250

27. ELLENBERG H 1986 Vegetation Mitteleuropas mit den Alpen. 4th Edition. Ulmer, Stuttgart, Germany, $988 \mathrm{pp}$

28. FÜHRER E, JAGODICS A, HORVÁTH L, MACHON A, SZABADOS I 2011 Application of a new aridity index in Hungarian forestry practice. Időjárás (Quarterly Journal of the Hungarian Meteorological Service) 115 (3): 205-216

29. RASZTOVITS E, BERKI I, MÁTYÁS CS, CZIMBER K, PÖTZELSBERGER E, MÓRICZ N 2014 The incorporation of extreme drought events improves models for beech persistence at its distribution limit. Ann Forest Sci 71 (2): 201210. http://dx.doi.org/10.1007/s13595-013-0346-0

30. STOJNIC S, SSASS-KLAASSEN U, ORLOVIC S, MATOVIĆ B, EILMANN B 2013 Plastic Growth response of European beech provenances to dry site conditions. IAWA J 34 (4): 475-484. DOI: http://dx.doi.org/10.1163/22941932-00000038 